\title{
The Employment View of Graduates in Local University of China
}

\author{
Xin Bi, Zengjiang Guo* \\ Polytechnic College, Hebei University of Science and Technology, Shijiazhuang, China \\ Email: ^guozj@hebust.edu.cn
}

How to cite this paper: $\mathrm{Bi}, \mathrm{X}$. and Guo, Z.J. (2016) The Employment View of Graduates in Local University of China. Open Journal of Social Sciences, 4, 119-123. http://dx.doi.org/10.4236/jss.2016.49011

Received: August 21, 2016

Accepted: September 18, 2016

Published: September 21, 2016

Copyright (c) 2016 by authors and Scientific Research Publishing Inc. This work is licensed under the Creative Commons Attribution International License (CC BY 4.0).

http://creativecommons.org/licenses/by/4.0/

\section{(c) (i) Open Access}

\begin{abstract}
Through literature review and open questionnaires, this research mainly explores the employment view of graduates in the local university of China, in order to find out the employment status and improve the employment pressure, so as to provide reference for the independent college graduate employment in the future.
\end{abstract}

\section{Keywords}

Employment View, Graduates, Local University

\section{Introduction}

Matching the demand for and supply of labour generally presents more difficulties for the youth segments of the labour force. The size of the gap between youth and overall unemployment rates, particularly in a number of European countries, has already been stressed in OECD for the purpose of policy interventions [1]. Hence, a UNESCO document emphasizes that while the number of students in higher education increases, greater attention must be paid to the quality of the graduating student skills and their relation to real-world workplace demands [2], which is in order to deal with the employment pressure in the future.

In recent years, China's higher education reform is unceasing, and the higher education is from "elite" to "popularization", which results in the fast rise in number of college students. Furthermore, at present overall employment situation in China is grim, especially the college students' employment status, which is influenced by the world economic downturn. Meanwhile, because the production department of labor demand has reduced greatly, a large number of layoffs and downsizing problems in a lot of enterprises, factory bankruptcy increase the social pressure of surplus labor, and this problem is still very prominent in recent years. On the other hand, since 1999 extensive enrollment expansion 
of colleges and universities in China, more and more college graduates with the average annual growth rate of $23 \%$ intensify the employment status [3]-[7].

A study carried out by the National Association of Universities and Institutions of Higher Education (ANUIES, in Spanish) [8] reveals that difficulty in finding employment affects $40 \%$ of university graduates, significantly affecting the total professional unemployment rate which is currently at $5.1 \%$. This rate can potentially increase significantly as Higher Education Institution (HEI) graduate unemployment will affect approximately 3 million persons in 2020 .

According to the statistics in China, in 2011, the number of college graduates in China had reached the peak, about 7.58 million graduates. The number of graduates was about 6.8 in 2012, 6.99 million in 2013, and 7.27 million in 2014, respectively. Moreover, in 2015 college graduates will amount to 7.49 million [9]. Hence, the next five to ten years will be the most difficult period of the employment of university graduates.

In order to find out the employment status and improve the employment pressure in the local universities of China, as the important components of China's higher education system, it is playing a noticeable role in both cultivating the talents and solving the problem of graduates' employment [10]. This paper explored the employment view of college graduates, so as to provide reference for the independent college graduate employment in the future.

\section{Methods}

Data were collected from graduates enrolling in the local universities in Hebei province of China. All questionnaires were released at the scene, there were 572 valid surveys out of 600 , with a valid rate of $95.3 \%$. The random sampling method was used in this study. The subject included $67.8 \%$ male and $32.2 \%$ female, 476 graduates were majored in science, and the other was arts students. 551 graduates were aged between 20 and 22, only 21 graduates were over 22 years old. The questionnaire had 25 items, which involved the personal information (department, profession, age, sex, etc.) of graduates, the awareness of employment situation (work place, work environment, etc.), professional prospects, starting salaries and career direction, and the impact of school course to employment, etc. For example, "How do you think the phenomenon of profession mismatch with work?", "Are you willing to choose their own business after graduating?", "what is your view on 'two-way choice, independent choosing profession' of employment policy?" etc.

\section{Results}

\subsection{Graduates Have No Idea about Employment Status}

The survey found that $87.5 \%$ of graduates thought employment status was not serious, only $6.3 \%$ of the graduates thought the serious employment status in the year of 2016 . It indicated that most graduates' employment cannot recognize the grim employment. Just as the analysis of Zhang [11] who is the director of the national institutions of higher learning student information counseling and career guidance center, ministry of 
education of China. The need of graduates increased obviously in the private enterprises, small and medium-sized enterprises, the second- and third-tier cities. The obvious difference still existed between the employment expectation of graduates and social demand. Overall, the severe employment situation was still complicated.

\subsection{Graduates Confuse Major Prospects and Career Planning}

The survey found that $72 \%$ of graduates thought the major prospects were so general. $25 \%$ of graduates had strong confidence on the major prospect. In the question of "to develop career planning for you to set up the correct problems are greatly", $40 \%$ of the graduates considered it was very necessary for them, $50 \%$ of graduates considered the help was not obvious, even nearly $10 \%$ of graduates considered that without any help. It indicated that the graduates did not understand the major prospects and planned in detail the career planning, even without planning.

\subsection{The Employment Concentration, Higher Expectations from Graduates}

The survey found that in the face of increasingly fierce employment competition pressure at present, $75 \%$ of the graduates had very high confidence, $18.8 \%$ of graduates had a little confidence. $50 \%$ of graduates expected to work in colleges and universities, scientific research units, $25 \%$ of graduates expected to work in the state-owned enterprises, $18.8 \%$ of graduates expected to work in the administrative organ, only $6.3 \%$ of the graduates preferred foreign-funded enterprises or private enterprises.

Nearly $80 \%$ of graduates hoped that the starting salary is $3000-4000$ yuan per month, when they graduated. That expectation of graduate employment direction was excessive concentration, however, the reality of enterprises in the employment, accounting for almost $50 \%$ of total employment graduates did not correspond to graduates employment and social needs.

\section{Recommendation and Conclusion}

\subsection{To Adjust Their Outlooks on Employment by Graduates Themselves}

The current global recession shows that employment problems are generated by the supply side because many graduates do not have the skills required by the labor market [12] [13]. So it is necessary to enhance the skills of graduates themselves.

Firstly, the graduates promoted the competitiveness of the self by realizing the employment status, analyzing the self quality and ability and basing on the expected employment direction. According to the needs of society, they definitely choose their jobs and direction though the analysis of the specialty or interest interests in all aspects.

Secondly, they should reduce employment expectation, also not too much to reduce employment expectation. Meanwhile, they consider the working space, opportunity and development for choosing a suitable job, which they also learn to accumulate work experience and ability, to create a better employment direction. 
Third, the graduates proceed self-employment by finding business opportunities and resources, because of the background of people' innovation and national business.

\subsection{To Offer Employment Opportunities for Graduates and to Strengthen Guidance from Local Universities}

Firstly, the universities help graduates to recognize themselves and actively guide the correct employment through teaching the career planning and employment guidance theory course. The universities theoretically teach professional graduates planning, combine the resources of the graduate employment status to analyze and guide correctly the graduates' reasonable employment.

Secondly, the universities strengthen the cooperation between colleges and enterprises to create more jobs for graduates. The university-enterprise cooperation broadens the students' knowledge in the college, and also exercises the students' ability in social work, and accumulates the ability of employment.

Third, the universities should perfect the campus entrepreneurial mechanism and encourage graduates to start up business. To enhance the publicity of entrepreneurial supporting policies from the nation, the universities help the students achieve business during the period of college.

\subsection{To Assist Graduates Employment from Families and Universities}

College students education is both the responsibility of the family and school, and university graduates employment is also so, though the analysis of family background, economic status, families and colleges helps the employment for graduates together. Because family socioeconomic status can expand to graduates employment channels, provide more and more valuable employment information for graduates and can also provide graduates with economic aid. Meanwhile, the families with higher socioeconomic status itself that have enough economic accumulation are not only in no hurry to drive their children's employment after graduation, but also have the ability to continue their children to go abroad to provide financial support, which possibly delays graduates employment.

Based on graduates themselves, college itself strength of university-enterprise cooperation and college students' family economic background, in general, the local universities of China should help graduates establish the correct employment view, straighten the employment expectation, integrate resources and improve the independent college graduates employment status.

\section{Acknowledgements}

This work was supported by the Project of Education and Teaching Reform in Polytechnic College of Hebei University of Science and Technology (ZX2015Y02).

\section{References}

[1] Potestio, P. (2011) The Employment of Young Graduates in the Period 2000-2010: A Comparison between Six European Countries. Modern Economy, 2, 880-892. 
http://dx.doi.org/10.4236/me.2011.25099

[2] UNESCO (2012) Education and Skills for Inclusive and Sustainable Development beyond 2015. http://www.un.org/millenniumgoals/pdf/Think\%20Pieces/4_education.pdf

[3] Qu, X.F., Zhang, J. and Wang, Y. (2015) A Study on College Graduates Employment Situation. Brand, 4, 154. http://www.cnki.net/kcms/detail/14.1289.F.20150511.1526.161.html

[4] Zhou, Y. (2015) A Study on the Employment View Problems and Countermeasures of College Students. Brand, 1, 176.

http://www.cnki.net/kcms/detail/14.1289.F.20150330.0931.280.html

[5] Chen, X.M. (2014) The Research on University Students' Employment under the Multidimensional Perspective. China Electric Power Education, 2, 227-229. http://www.cnki.net/kcms/doi/1007-0079(2014)02-0227-03.html

[6] Ai, L.R. (2015) Study on Undergraduates Employment Ideological Education Practice. Creative Education, 6, 309-314. http://dx.doi.org/10.4236/ce.2015.63029

[7] Dai, L.T. and Xiao, R. (2016) The Influence of Social Comparison on Job Performance. Open Journal of Social Sciences, 4, 147-151. http://dx.doi.org/10.4236/jss.2016.47024

[8] ANUIES (2013) Educación, Mercado de Trabajo, Satisfacción Laboral. ANUIES, México.

[9] (2015) 7.49 Million College Graduates Employment Demand and Structural Changes in 2015. China Education Online, Employment Channels.

http://career.eol.cn/kuai_xun_4343/20141205/t20141205_1209756.shtml

[10] Wang, D.J., Zhu, Q.X. and Lin, Y. (2013) Study on the Problems Existing in the Employment Education for College Students in China's Independent Colleges and Corresponding Countermeasures. Creative Education, 4, 470-473. http://dx.doi.org/10.4236/ce.2013.47068

[11] Zhang, F.Y. (2015) The Employment Status and Employment Policy Was Read by the Director of the Career Guidance Center, Ministry of Education. China University Students Career Guide, 1, 7-8. http://www.cnki.com.cn/Article/CJFDTotal-JIUY201501005.htm

[12] Burnett, N. (2008) The New Dynamics of Higher Education: Meeting the Challenges of Equity, Quality and Social Responsibility. OECD/France International Conference-Higher Education to 2030: What Futures for Quality Access in the Era of Globalization? http://unesdoc.unesco.org/images/0018/001808/180891e.pdf

[13] Sharma, Y. (2013) A Focus on Skills Increasingly Links Higher Education with Employment. University World News. http://www.universityworldnews.com 
Submit or recommend next manuscript to SCIRP and we will provide best service for you:

Accepting pre-submission inquiries through Email, Facebook, LinkedIn, Twitter, etc. A wide selection of journals (inclusive of 9 subjects, more than 200 journals)

Providing 24-hour high-quality service

User-friendly online submission system

Fair and swift peer-review system

Efficient typesetting and proofreading procedure

Display of the result of downloads and visits, as well as the number of cited articles

Maximum dissemination of your research work

Submit your manuscript at: http://papersubmission.scirp.org/

Or contact jss@scirp.org 